\title{
The Silviculture Conference
}

\section{What will it take? Policy needs of intensive silviculture}

\author{
by Peter N. Duinker
}

\section{Introduction}

The topic I was asked by the conference organizers to address was "policy changes required in Canada in order to practice more-intensive silviculture". It would help one to address this topic if one truly believed that this is what ought to happen in Canadian forest management. I am not ready to accept this position. Silviculture can be seen simultaneously as one person's means and another person's ends. The former might be the forest manager, the latter the silvicultural contractor. I regard silviculture as a means, so I take the perspective of a forest manager. If the objective of silviculture is to achieve forest conditions that support a target wood supply and other forest-level goals, then the question of whether silviculture should be intensified depends entirely on how much silviculture is needed in a particular forest to achieve the forest goals. There is no generalizable yet sensible answer to this question.

However, I am willing to reflect on the conditions I think would have to prevail in Canada before more-intensive silviculture would be practiced. I put it this way because I believe that the wrong approach would be for forest policy to force more-intensive silviculture to happen. This is like pushing on a rope. Rather, the right approach would be to establish a favourable environment (to the degree possible) in which more-intensive silviculture could happen, and then if it should happen it can.

In this paper I will identify several conditions that would need to be met for increased implementation of intensive silviculture, and then reflect on the policies that might be helpful in bringing those conditions about.

\section{Conditions for more-intensive silviculture}

1. Public and Professional Acceptance of Intensive Treatments

In my view, debates about forest management ought to focus on objectives to be achieved, especially regarding the condition and structure of the evolving forest landscape. Debates that focus on the desirability of forest practices usually lose sight of what impacts those practices have, collectively, on forest structure and condition and on socio-economic systems. However, environmental groups, the general public, and even many forestry professionals still want to argue about whether clearcutting or herbicide use, for examples, are right or wrong. This infatuation with tools and techniques rather than results at the landscape level will continue. Many of the techniques of intensive silviculture are subject to these debates - scarification, planting, chemical tending, etc.

Can people be convinced that any ill-effects of intensive silvicultural treatments are well worth bearing given the great rewards to be gained? To the degree that this is indeed true, then yes, to some degree. Public relations efforts and adversarial

Associate Professor and Chair in Forest Management and Policy, School of Forestry, Lakehead University, Thunder Bay, Ontario P7B 5E1.

Paper presented at the Silviculture Conference, Toronto, Ontario, September 1993. approaches to bringing science into public debate, like the Class EA for Timber Management on Crown Lands in Ontario, do not help much. We need more: (a) touring of the woods by the public in the company of dedicated, knowledgeable and sincere forestry professionals; and (b) quantitative analyses which provide evidence as to the long-term, broad-scale consequences, both desirable and undesirable, of alternative silvicultural strategies. Woodlands tours are becoming prevalent across the country, a very welcome sign. We are still woefully short of good studies, especially quantitative case analyses, of what might be lost and gained by changing silvicultural strategies. Research policies and programs could use some redirection.

\section{The So-called Allowable-cut Effect of Silviculture}

I believe that silviculture on large forest estates in Canada will never intensify to any appreciable degree if forest managers do not accept and apply the concept of the allowable-cut effect (ACE) of silviculture. They also need to communicate to the public that any forest has a range of possible sustainable (even-flow) harvest levels, each dependent upon a defined program of management inputs and actions, including silviculture.

Here is my reasoning. Harvest levels in large forests are always set on the basis of expectations of long-term growth of timber on every hectare available for timber production. Silvicultural treatments are strong determinants of the forester's expectations of timber growth on the areas treated. Analyses of wholeforest dynamics in many Canadian timber-producing forests reveals that implementation of silviculture today to improve timber growth on the treated hectares permits an immediate increase in the long-run, even-flow timber harvest from the whole forest. The size of the increase in harvest level depends on the degree to which the silvicultural treatments alter stand development patterns where the treatments are applied, and on the initial structure of the forest, particularly its type and age-class structures. This means that silvicultural treatments are justified not on the basis of what benefits they might bring on the treated areas alone, but rather on how the responses on the treated areas permit adjustments in management, particularly the scheduling of timber harvests, in the rest of the forest. Silvicultural treatments in much of Canada are a money-losing proposition, as investments securing future gains, on a hectareby-hectare basis, but in many cases can look financially attractive on a whole-forest basis.

Some will caution that we have too little information to make good projections of the timber-growth responses of Canadian stands to the wide range of silvicultural treatments available. Thus, forest-inventory projections based on more-intensive silviculture are extremely uncertain. I agree, but we are uncomfortably ignorant about stand responses to any kind or level of human disturbance. Projections of the behaviour of current forest stands, and of natural regeneration following clearcutting, are as uncertain as those of intensively treated stands following timber harvest. Thus, forest harvest levels based on lowintensity silviculture like natural regeneration are shaky, too. Under all circumstances, we must be cautious in yield projections, 
for it will be better in the future to have something we don't need than to need something we don't have.

Will forest managers, and particularly forest scientists, let go of hectare-by-hectare analyses to justify or reject silvicultural alternatives for large timber-producing forests? Perhaps this will happen when provincial agencies in charge of public forest land insist on volume-based forest simulation as a basis for establishment of both timber-harvest levels and associated silvicultural programs. Ontario has yet to do this.

\section{Favourable Relationships between Timber Demands and the Timber Landbase}

The demand for timber from Canada's forests could go down, stay the same, or increase. Demand forecasting is a risky and complex business, but the most likely scenario for me is that demands will increase. Similarly, the landbase available for timber production could increase, stay the same, or go down. I'll put my money on the landbase shrinking somewhat in the next decade.

If these trends come to pass, things will look good for the silviculture industry. It is hard to imagine how timber demands could be met over the long haul if the timber landbase shrinks and silviculture is not intensified somewhat. To look at the situation perversely, perhaps the silviculture industry should lobby hard for withdrawals from the timber landbase. To keep the Canadian forest-products manufacturing industry going, silviculture would have to be intensified. Perhaps a case could be made this way: if the people of Canada want more forest land protected from timber management (as well as wanting vigorous amounts of industrial activity and employment based on wood), they may well at the same time have to accept intensification of silviculture on many lands remaining in the timber landbase.

Policies that remove forest landbase from timber production, and that favour increases in the industrial processing of wood, will lead to intensification of silviculture.

\section{Higher Monetary Value for Roundwood}

Intensive silvicultural treatments represent substantial costs to forest managers. I believe that the monies to pay for such treatments, if they are to occur, will have to come directly or indirectly from timber sales or wood-products manufacturing. Provincial and federal coffers are unlikely sources, given current and projected deficits and society's appetite for social programs.

Of course one can only charge for roundwood what the market will bear, or else there would be no transactions and thus no market. But in many parts of Canada, there is hardly the type of roundwood market, on the stump or deliverable to millgates, where vigorous competition exists with many independent buyers and many independent sellers. Many have argued that Canadian roundwood is priced too low, and if it were priced higher, more-intensive silviculture could be afforded. So why not jack up the price? Well, can Canadian industries remain internationally competitive and pay more for roundwood? This is highly company- and product-dependent, so a general answer is meaningless.

Whatever the complex cause-effect linkages in the economic system, I conclude that the money to pay for more-intensive silviculture will have to come from sales of wood and wood products. More money from such sales can only come from more volume sold or higher unit prices. The key for silviculture will be to ensure that, if more-intensive silviculture is desired and intended, the increased revenues from roundwood and wood products do indeed go to silviculture.

\section{Responsibilities for Undertaking and Paying for Silviculture}

I believe it was wise in recent decades to have Canadian industrial timber-tenure holders who would harvest wood from public forests also plan and execute regeneration silviculture. Wiser still in my view is to have the tenure holder pay for the treatments. This begets efficiency in meeting forest objectives, but also puts production costs in the hands of the institution driven by profit motive. If the cost of units of input is exceeded by the revenues of the additional units of production that result, the profit-motivated institution will bear the costs. What incentives do public owners have to bear silvicultural costs on public land, especially when wood seems to have a low price? Profit-motivated institutions like private-enterprise timbertenure holders at least can search for profit-producing possibilities from silviculture when they bear the costs. This is impossible in tenure arrangements where government bears silvicultural costs.

There are several ways to set up timber-tenure arrangements for public land where the tenant bears silvicultural costs. I favour the idea of private enterprise renting the productive structure of a forest landscape from government. The productive structure includes not only the land but also the current forest, because the timber-producing potential of a forest over the short term (say, a few decades) is so strongly determined by the type and age-class structure of its component stands. At any instance, not all cubic metres of timber growing stock in a forest are equal in ability to produce new growing stock. There are strong differences among stand types (tree species) and tree ages.

The tenant (forest-management company) and landlord (government) would use the same forest inventory and analytical framework to explore alternative timber-production possibilities and future forest structures, on the basis of which they would negotiate (a) the annual rental price, (b) the desired forest structure to be maintained through the duration of the contract, (c) how broad-scale disturbances like fire and insect infestation will be dealt with, and (d) any basic ecological stewardship requirements affecting forest practices. The tenant would be free to determine timber harvest levels and silviculture programs. The assumption is that a wide range of timber harvest levels and associated silviculture programs could be implemented by the tenant while the tenant meets all the conditions specified in the contract, especially the maintenance of the required forest structure.

\section{Conclusions}

The reader is welcomed to ponder whether and how the conditions described above might need to be fulfilled before more-intensive silviculture is practiced widely in Canada. Will more-intensive silviculture automatically happen even if all these conditions are met? I believe it will be facilitated, but not by definition therefore practiced. To recap, the conditions that will help are:

1. Acceptance of the practices of intensive silviculture by the public and by forestry professionals; 
2. Acceptance of the concept of the allowable-cut effect of silviculture;

3. A shrinking timber landbase or increasing demands for roundwood;

4. Higher prices for roundwood; and

5. Having those who receive revenue for harvested roundwood pay for silviculture.

But have we been tackling the right question? Should the future be full of intensive silviculture across Canada? Silvicultural contractors might say yes. Many others would say no, and yet others would say it depends - in some cases yes, in others no. I am in this last group. My only firm conclusions on this topic are:

1. Intensive silviculture ought not to be pushed by technique practitioners or proponents - it is attached to a rope that must be pulled by forest owners and managers.

2. There are several plausible scenarios under which conditions for the widespread practice of more-intensive silviculture could occur. Some policy shifts could help create these conditions.

3. From a forest-management point of view, what we really want, everywhere, is not more-intensive silviculture, but rather affordable, smart silviculture - the gentlest intrusions into forest ecosystems that get the required job done.

\section{Frais d'adhésion 1993-1994}

Membre actif

Première et deuxième année suivant la graduation (graduation de 1991 et de 1992$) *(2.49$ \$ de T.P.S. inclus)

Nouveau membre pour une première année $*(2.49 \$$ de T.P.S. inclus)

Marié ou équivalent

Deuxième adhésion seulement $*(2.49 \$$ de T.P.S. inclus $)$

Tout autre membre actif $*(2.49 \$$ de T.P.S. inclus $)$

\section{Autres catégories de membres}

Membre à la retraite (afin d'obtenir le statut de membre à la retraite, ce dernier doit être membre de l'Institut depuis quinze ans)

*(2.49 \$ de T.P.S. inclus)

Membre étudiant *(1.31 \$ de T.P.S. inclus)

Membre de soutien (membre de l'IFC/CIF)

Membre corporatif *(4.98 \$ de T.P.S. inclus)

Suite à une demande écrite, le conjoint d'un membre actif peut obtenir une réduction de ses frais d'adhésion en fonction d'un mon tant déterminé annuellement. Les membres conjoints sont membres d'une même section, demeurent ensemble en tant que conjoints et utilisent la même adresse postale.

L'année budgétaire de l'Institut débute le 1er juillet pour se terminer le 30 juin. Les demandes d'adhésion effectuées après le 1er janvier 1992, seront facturées à la moitié des frais d'adhésion de l'Institut pour l'année en cours. Aucun frais d'adhésion ne sera facturé au membre soumettant une demande après le ler avril pour la durée de l'année en cours.

Le frais de section s'additionnent à ce montant et varient de 5.00 \$à 30.00 \$ pour l'année budgetaire de l'Institut.

*N.B.: La portion des frais d'adhésion couvrant les frais du Forestry Chronicle est assujettie à la T.P.S. Pour les fins de la taxe, ce coût est calculé sur une base de 38.00 \$ et correspond à 2.49 \$ de T.P.S. (sauf pour le taux étudiant de 20.00 \$, soit 1.31 \$ de T.P.S.) 